\title{
Potential of the Mycoparasite, Verticillium lecanii, to Protect Citrus Fruit Against Penicillium digitatum, the Causal Agent of Green Mold: A Comparison with the Effect of Chitosan
}

\author{
Nicole Benhamou
}

Recherche en Sciences de la vie et de la santé, Pavillon Charles-Eugène Marchand, Université Laval, Sainte-Foy, Québec, Canada, G1K 7P4. Accepted for publication 23 January 2004.

\begin{abstract}
Benhamou, N. 2004. Potential of the mycoparasite, Verticillium lecanii, to protect citrus fruit against Penicillium digitatum, the causal agent of green mold: A comparison with the effect of chitosan. Phytopathology 94:693705.

The potential of the mycoparasite, Verticillium lecanii, at protecting citrus fruits against green mold was explored at the cellular level. Treatment of the fruit with $V$. lecanii or chitosan prior to inoculation with the causal agent of green mold, Penicillium digitatum, markedly reduced disease development compared with that of nontreated control citrus fruits in which symptoms were visible by 3 days after inoculation with the pathogen. Scanning electron microscope investigations of citrus samples, collected 5 days after inoculation with the pathogen, revealed striking differences in the extent of cell surface colonization between treated and nontreated fruits. Pathogen hyphae, which sporulated abundantly at the surface of control fruits, were collapsed and severely damaged in V. lecaniiand chitosan-treated fruits. Histological observations of citrus samples

observed. Ultrastructural investigations of citrus samples revealed that the pathogen multiplied abundantly through much of the mesocarp and exocarp tissues in $V$. lecanii-free citrus fruits, whereas in V. lecanii-treated citrus, pathogen growth was restricted. Penicillium hyphae that penetrated the mesocarp tissue were markedly altered. Labeling with the wheat germ agglutinin/ovomucoid-gold complex for the localization of chitin resulted in an irregular labeling of Penicillium cell walls, even at a time when these were markedly altered. Cytochemical investigations revealed that callose and lignin-like compounds accumulated at sites of pathogen colonization in the exocarp tissue. Evidence is provided in this study that $V$. lecanii as well as chitosan are equally capable of inducing a striking response in $P$. digitatum-infected citrus fruits. The marked differences observed in the rate and extent of colonization as well as in pathogen cell viability between control and treated citrus fruits demonstrate that both treatments have the ability to induce the transcriptional activation of defense genes leading to the accumulation of structural and biochemical compounds at strategic sites.
\end{abstract} confirmed that restriction of pathogen colonization at the cell surface correlated with a pronounced disorganization of the pathogen hyphae. In addition, host cell changes, mainly characterized by the deposition of a new material in the exocarp cells and the thickening of cell walls, were
Additional keywords: biological control, fungal-mediated induced resistance, gold cytochemistry, postharvest disease management.
In the past decade, the advances in molecular biology and plant transformation, culminating with the accumulation of abundant information on the signal transduction pathways linked between perception of pathogen attack and elaboration of plant defense responses, have opened novel avenues for biotechnological applications in agriculture $(10,25)$. From these fundamental studies, it appeared clearly that sensitizing a plant to respond more rapidly to infection could confer increased protection against virulent pathogens (36). Understandably, a question that has challenged many scientists was how induced resistance could be rationally exploited as an alternative for controlling pre- and postharvest diseases (46). However, in spite of major progress in our understanding of how to manipulate the plant's defense strategy, examples of practical use of induced resistance as a biological control method are few, even though encouraging results have been obtained upon plant or fruit treatment with chitosan $(14,26)$, UV-C light $(23,28)$, beneficial microorganisms (45), and antagonistic fungi $(34,47)$. While these biological approaches may not match the efficacy of some fungicides with systemic action (i.e., thiabendazole), the possibility for biocontrol agents to induce satisfactory protection of plants and commodities is a viable alternative, provided that specific requirements, including human safety

Corresponding author: N. Benhamou; E-mail address: nben@ rsvs.ulaval.ca

Publication no. P-2004-0430-01R

(C) 2004 The American Phytopathological Society and knowledge about the exact mode of action of the selected biological approach, are met (34).

Postharvest green mold of citrus, caused by Penicillium digitatum (Pers.:Fr) Sacc., is responsible for major economic losses for the citrus industry (21). In recent years, the development of fungal resistance to many fungicides and the growing consumer concern over pesticide contamination of food have prompted the search for alternative control strategies (46). In line with this concept, a number of studies have documented that selected bacterial strains such as Pseudomonas syringae (20), Bacillus subtilis (4), and Bacillus pumilus (33) as well as yeast isolates including Pichia guilliermondii and Candida famata $(2,3)$ could exert beneficial effects on the protection of citrus fruits against $P$. digitatumincited disease mainly through competition for nutrients and antibiosis.

Another promising microorganism that has potential to protect citrus fruit from disease is the mycoparasite Verticillium lecanii (Zimm.) Vegas. The ability of this well-known entomopathogenic fungus (43) to induce plant defense mechanisms was not fully appreciated until recent years (12), although its ability to antagonize a number of pathogenic fungi including powdery mildew $(5,6,38)$, rusts (44), and green mold pathogens (11) has been documented. Despite the amount of research devoted to elucidating the mechanisms by which $V$. lecanii exerts its antimicrobial activity $(17,42)$, our knowledge regarding the involvement of the host itself in plant-pathogen interactions is still developing, although a recent report demonstrated that $V$. lecanii-mediated in- 
duced resistance was a crucial event in the complex process of disease protection in cucumber (12). This study highlighted, for the first time, the dual properties of $V$. lecanii which, in addition to being a strong antagonist in the rhizosphere, was also capable of evoking biochemical events characteristic of the natural plant disease resistance process. The early in vitro demonstration that $P$. digitatum was highly vulnerable to $V$. lecanii (11), together with the recent finding that $V$. lecanii could also operate as an inducer of plant disease resistance (12) led us to hypothesize that this antagonistic fungus could protect citrus fruits from green mold by a combination of mechanisms including direct antimicrobial activity and fruit induced resistance.

In an attempt to address this issue, the objectives of the present research were first to investigate ultrastructurally the outcome of the citrus $-P$. digitatum interaction upon $V$. lecanii treatment, second to delineate the cytological and biochemical changes associated with pathogen alteration in planta, and third to compare the extent and magnitude of the host response to that observed upon treatment with chitosan, a well-known inducer of plant defense mechanisms $(10,14-16,26,27,46)$. As a prelude to further investigations of the effect of $V$. lecanii on citrus protection from $P$. digitatum-incited disease under semicommercial conditions, the present study was undertaken at an experimental level to gain a better insight into the specific relationship established between the fruit, the pathogen, and the antagonist. Evidence is provided that $V$. lecanii not only acts as a powerful antagonist of $P$. digitatum but also triggers the induction of defense reactions in citrus fruits.

\section{MATERIALS AND METHODS}

Fungal cultures and growth conditions. The antagonistic fungus, V. lecanii (strain DAOM 198499), collected from codling moths in Quebec, was provided by W. R. Jarvis, Harrow Research Station Agriculture and Agrifood Canada, Ontario. The pathogenic fungus, $P$. digitatum (isolate SRSF707, known to be highly virulent on citrus fruits), was obtained from the collection maintained at Agriculture and Agrifood Canada, Sainte-Foy, Québec. Both fungi were routinely grown on potato dextrose agar (PDA, Difco Laboratories, Detroit) at $24^{\circ} \mathrm{C}$ in the dark and subcultured weekly.

Preparation of chitosan. Chitosan (Sigma Chemical, St. Louis) was prepared according to a previously described procedure (16). Briefly, it was ground to a powder by extensive grinding, washed repeatedly in distilled water, pelleted by low-speed centrifugation, and air-dried. Sheets of chitosan were solubilized by stirring in $0.25 \mathrm{~N} \mathrm{HCl}$, centrifuged at $10,000 \times g$ for $10 \mathrm{~min}$ to remove the insoluble material, and precipitated by neutralization with $2.5 \mathrm{~N}$ $\mathrm{NaOH}$. The chitosan pellets, recovered by centrifugation at $25,000 \times g$ for $15 \mathrm{~min}$, were thoroughly washed with deionized water to remove salts and freeze-dried. For experimental use, purified chitosan was dissolved in $0.05 \mathrm{~N} \mathrm{HCl}$ under continuous stirring, and the $\mathrm{pH}$ was adjusted to 5.5 with $2 \mathrm{~N} \mathrm{NaOH}$ to obtain a concentration of $10 \mathrm{mg} \mathrm{ml}^{-1}$ (stock solution). The resulting solution was diluted in the plant nutrient solution to obtain a $\mathrm{pH}$ of 5.8 and final chitosan concentrations corresponding to 1 and $2 \mathrm{mg} \mathrm{ml}^{-1}$. The amount of $\mathrm{NaCl}$ formed in the chitosan solution was estimated to be less than $0.05 \mathrm{M}$.

Citrus fruit pretreatment and fungal pathogen inoculation. Commercially available lemon fruits (Citrus lemon L.) with no visible wounds were surface-sterilized by immersion in ethyl alcohol at $90 \%$ for $10 \mathrm{~min}$ and allowed to dry at room temperature under sterile conditions. Fruits were artificially wounded at two to three sites with a sterile razor blade to a depth of $5 \mathrm{~mm}$. For chitosan treatment, $20 \mu \mathrm{g}$ of the chitosan solution $\left(1 \mathrm{mg} \mathrm{ml}^{-1}\right)$ was directly applied onto the fresh wounds. For treatment with V. lecanii, a plug (3-mm diameter) of actively growing mycelium of $V$. lecanii was introduced into the wounds. Control wounds were treated with either sterile distilled water or with fungus-free agar plugs. Fruits were placed in plastic cavity packaging trays with 10 fruits per tray. The cavity trays were chosen because they allow to isolate each fruit, thus avoiding contact infection or contamination. The trays were maintained at $24^{\circ} \mathrm{C}$ with a relative humidity of $90 \%$ for 2 days. Wounded fruits were, thereafter, challenge-inoculated by introducing one plug (3-mm diameter) of actively growing mycelium of $P$. digitatum onto the wounds. Such an inoculation method was selected to accelerate the infection process of citrus fruits by the pathogen. Control wounds were treated with fungus-free PDA plugs. There were five fruits per replicate and three replicates per treatment. Symptoms of green mold associated with the development of $P$. digitatum were visualized daily and wounded, inoculated samples were collected 3,4 , and 5 days after inoculation with the pathogen for electron microscope investigations.

Tissue processing for scanning electron microscopy (SEM). Samples $\left(1 \mathrm{~cm}^{2}\right)$ from wounded control and challenged citrus fruits were vapor-fixed with $2 \%$ (wt/vol) osmium tetroxide in distilled water for $20 \mathrm{~h}$ at room temperature, air-dried, and sputter-coated with gold palladium in a Nanotech sputter coater (Cambridge Scientific Industries, Cambridge, MA). Samples were kept in a desiccator until examination with a scanning electron microscope (JEOL JSM-35CF; JEOL, Tokyo, Japan) operating at $15 \mathrm{kV}$. Micrographs were taken on Polaroid type 52 film (Polaroid Corp., Cambridge, MA). Two samples per treatment per time period were examined.

Tissue processing for light and transmission electron microscopy (TEM). Samples from wounded control and challenged citrus fruits $\left(2 \mathrm{~mm}^{3}\right)$ were carefully excised and immersed in 3\% (vol/vol) glutaraldehyde in $0.1 \mathrm{M}$ sodium cacodylate buffer, $\mathrm{pH}$ 7.2 , for $2 \mathrm{~h}$ at room temperature. Samples were subsequently postfixed with $1 \%(\mathrm{wt} / \mathrm{vol}$ ) osmium tetroxide in the same buffer for $1 \mathrm{~h}$ at $4^{\circ} \mathrm{C}$ and dehydrated in a graded ethanol series prior to embedding in Epon 812.

Thin sections $(0.7 \mu \mathrm{m})$, cut from the Epon-embedded material with glass knives, were mounted on glass slides and routinely stained with $1 \%$ aqueous toluidine blue prior to examination with a Zeiss Axioscope microscope (Carl Zeiss Canada, Ontario). Some sections were stained with methylene blue-basic fushin modified from the procedure of Aparicio and Marsden (1). The staining procedure included first an incubation of the sections for $15 \mathrm{~min}$ at $56^{\circ} \mathrm{C}$ in a mixture of methylene blue ( $1 \%$ in distilled water), toluidine-O $(0.25 \%$ in distilled water), and borax ( $2 \%$ in distilled water) followed by a thorough washing in bidistilled water, and second an incubation in basic fushin $(0.5 \%$ in distilled water) for $3 \mathrm{~min}$ at room temperature. Such a procedure results in a differential histological staining of the plant cell components with the cytoplasm and organelles (blue-violet), the cuticle and the cellulose (pink-red), and the lignin (blue-green).

Ultrathin sections were collected on Formvar-coated nickel grids and were either contrasted with uranyl acetate and lead citrate for direct examination with a JEOL 1200 EX electron microscope operating at $80 \mathrm{kV}$ or processed for cytochemical labeling. For each treatment, an average of five samples from three different fruits were examined using 10 sections per sample.

Preparation of the colloidal gold probes. Colloidal gold with particles averaging $15 \mathrm{~nm}$ in diameter was prepared according to Frens (29). For the localization of cellulosic $\beta$-1,4-glucans, an exoglucanase ( $\beta$-1,4-D-glucan cellobiohydrolase, EC 3.2.1.21), purified from a cellulase produced by the fungus Trichoderma harzianum, was complexed to colloidal gold at $\mathrm{pH} 9.0$ and used in a one-step procedure (13). Wheat germ agglutinin (WGA), a lectin with $N$-acetylglucosamine binding specificity was used for localizing fungal chitin according to a previously described procedure (8). Because of its low molecular weight, this lectin could not be directly complexed to colloidal gold. It was used in a twostep procedure, using ovomucoid as a second step reagent. Ovo- 
mucoid was conjugated to gold at $\mathrm{pH} 5.4$ (8). Callose, a polymer of $\beta$-1,3-glucans, was localized using a purified tobacco $\beta-1,3$ glucanase complexed to colloidal gold according to the method described by Benhamou (9). Localization of lignin-associated phenolic compounds was performed by using a laccase (EC 1.10.3.2) purified from the white rot fungus Rigidoporus lignosus (31). The enzyme was complexed to colloidal gold at $\mathrm{pH} 4.0$, a $\mathrm{pH}$ value close to its isoelectric point reported to be 3.83 (15). All gold complexes were stored at $4^{\circ} \mathrm{C}$ until use.

Cytochemical labeling. For direct labeling with the enzymegold complexes, ultrathin sections, mounted on nickel grids, were first floated for $5 \mathrm{~min}$ on a drop of $0.01 \mathrm{M}$ sodium phosphatebuffered saline (PBS) containing $0.02 \%$ of polyethylene glycol 20000 (PEG 20000) at the $\mathrm{pH}$ corresponding to the optimal activity of the protein tested (6.0 for the three tested enzymes). Sections were then transferred to a drop of each gold-complexed enzyme for 30 to $60 \mathrm{~min}$, at room temperature, in a moist chamber. They were washed thoroughly with PBS ( $\mathrm{pH} 7.4$ ), rinsed with distilled water, and allowed to dry before staining with uranyl acetate and lead citrate.

For the indirect labeling of $\mathrm{N}$-acetylglucosamine residues, sections were first floated on a drop of PBS ( $\mathrm{pH} 7.4)$ for $5 \mathrm{~min}$ and then transferred to a drop of WGA $(25 \mu \mathrm{g} / \mathrm{ml}$ in PBS, $\mathrm{pH} 7.4)$ for $60 \mathrm{~min}$ at room temperature in a moist chamber. After washing with PBS ( $\mathrm{pH} 7.4)$, sections were incubated on a drop of the ovomucoid-gold complex for $30 \mathrm{~min}$ at room temperature. Sections were washed with PBS, rinsed with distilled water, and contrasted as described previously.

Specificity of the different labelings was assessed by the following control tests: (i) addition of the corresponding substrate to each protein-gold complex for a competition experiment: $\beta$ 1,4-glucans from barley $\left(1 \mathrm{mg} \mathrm{ml}^{-1}\right)$ for the $\beta$-1,4-exoglucanasegold complex, laminarin $\left(1 \mathrm{mg} \mathrm{m}^{-1}\right)$ for the $\beta$-1,3-glucanase, and $p$-coumaric acid, ferulic acid, or sinapinic acid for the laccase (1 $\mathrm{mg} / \mathrm{ml}^{-1}$ ); (ii) substitution of the protein-gold complex under study by bovine serum albumin-gold complex to assess the nonspecific adsorption of the protein-gold complex to the tissue sections; (iii) incubation of the tissue sections with the protein-gold complexes under nonoptimal conditions for biological activity; (iv) incubation of the tissue sections with colloidal gold alone to assess the nonspecific adsorption of the gold particles to the tissue sections; and (v) for the indirect labeling of chitin, controls included both incubation with the WGA to which was previously added an excess of $N-N^{\prime}-N^{\prime \prime}$-triacetylchitotriose (1 mg/ml in PBS) and incubation with WGA, followed by unlabeled ovomucoid and finally by ovomucoid-gold complex.

Reagents. The exoglucanase was provided by C. Breuil, Forintek, Canada, and the laccase was obtained from M. Nicole, ORSTOM, Montpellier, France. Tetrachloroauric acid was purchased from BDH Chemicals, Montreal, Canada. All other reagents for electron microscopy were obtained from JBEM Chemical Co., Pointe-Claire, Québec, Canada.

\section{RESULTS}

Effect of chitosan and $V$. lecanii on the development of citrus green mold. Within 3 days after inoculation with $P$. digitatum, wounded, untreated citrus fruits were characterized by the development of slightly discolored spots that rapidly became soft and watery. In the following days, a white mold covered the spots (Fig. 1A) and started producing olive green spores (Fig. 1A, double arrows). The sporulating areas enlarged rapidly and invaded the entire fruits by 5 days after inoculation.

Treatment with $V$. lecanii substantially reduced the incidence of green mold caused by $P$. digitatum (Fig. 1B). By 3 days after inoculation with the pathogen, some slight watery spots were visible in the immediate vicinity of the wounds (Fig. 1B, arrows). A white mycelium of $P$. digitatum developed thereafter in the wounds but did not spray beyond. By 5 days after inoculation, invasion by the pathogen was restricted to the wounds without any further colonization of the surrounding tissues. Sporulation was never observed (Fig. 1B).

Application of chitosan to wounded fruits prior to inoculation with $P$. digitatum resulted in a near absence of fungal development in the wounds that were bordered by a reddish scar (Fig. 1C, arrows). Typical symptoms of the disease such as discolored,
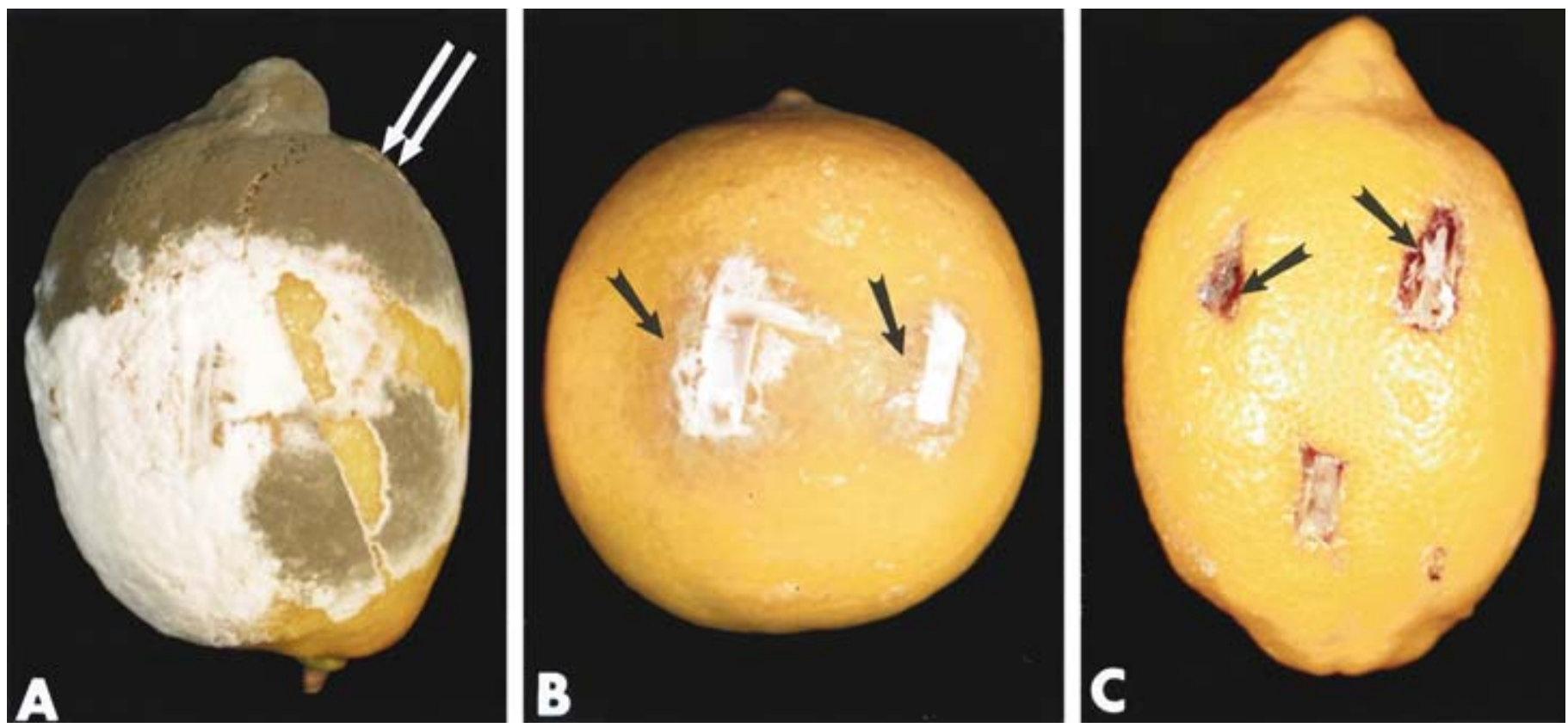

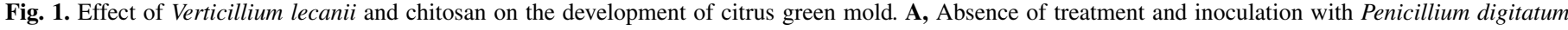

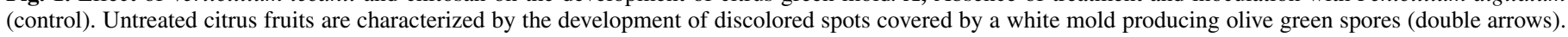

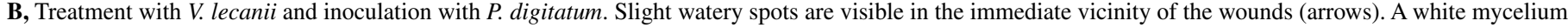

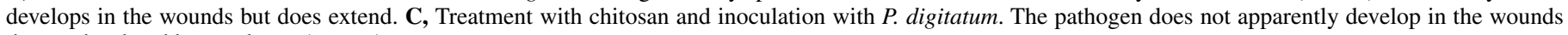
that are bordered by a red scar (arrows). 
watery spots and white mycelial network were not detected, even within 5 to 7 days after inoculation.

SEM investigations of the effect of chitosan and $V$. lecanii on growth of $P$. digitatum in wounded citrus fruits. Examination of samples from untreated citrus fruits, collected 5 days after inoculation with $P$. digitatum, revealed that the fungus proliferated rapidly at the cell surface (Fig. 2A). Observation of several samples from five different citrus fruits provided evidence that the pathogen formed a dense, branched mycelium that sporulated abundantly (Fig. 2A and B). Hyphae were turgescent and the massive sporulation led to the formation of typical conidiophores (Fig. 2B).

Observations of pathogen-inoculated samples collected from citrus fruits treated with $V$. lecanii showed that pathogen development at the cell surface was greatly reduced compared with that observed over control, inoculated citrus samples (Fig. 2C and D). Hyphae of $V$. lecanii, which were easily distinguished from
$P$. digitatum hyphae by hyphal diameter and density, were found to establish close contact with the pathogen by means of coiling (Fig. 2C). Signs of collapse, evidenced by the shrinked appearance of the pathogen cell surface (Fig. 2C), were often observed by 3 days after inoculation and markedly increased in the following days (Fig. 2D, white arrow). Pronounced collapse and loss of turgor of $P$. digitatum hyphae were among the most typical features of alteration observed by 5 days after inoculation (data not shown). Such altered hyphae did not sporulate as shown by the absence of spores around the mycelium network.

SEM investigation of samples collected from chitosan-treated citrus fruits showed that cells of $P$. digitatum were seriously damaged as early as 3 days after pathogen inoculation (Fig. 2E). Most hyphae of the pathogen (about 95\%) were collapsed and plasmolysed. Sporulation was never observed.

Light microscope investigations of the effect of chitosan and $V$. lecanii on growth of $P$. digitatum in wounded citrus fruits.
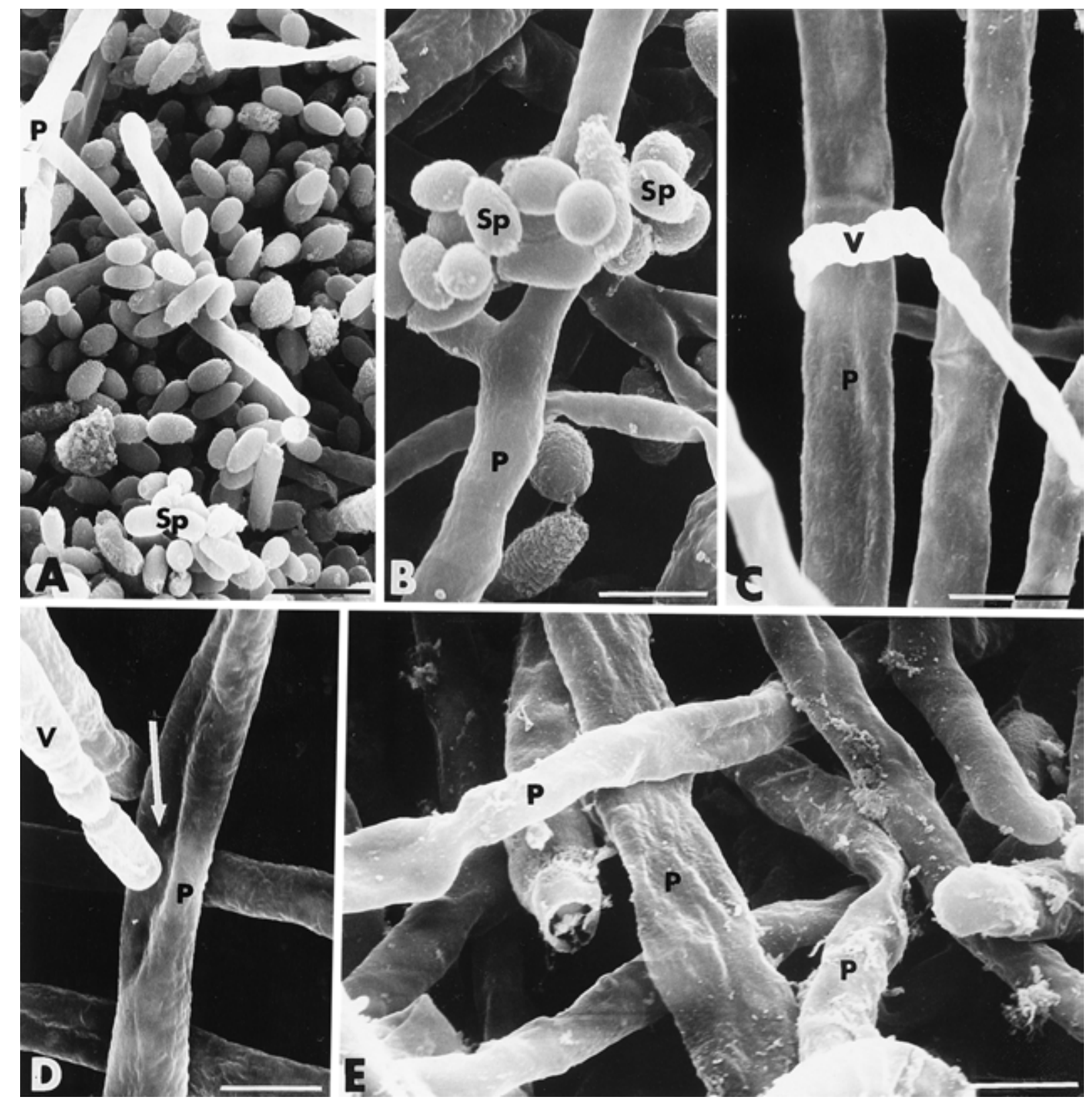

Fig. 2. Scanning electron micrographs of samples from wounded citrus fruits inoculated with Penicillium digitatum. A and B, In untreated citrus fruits (controls), P. digitatum $(\mathrm{P})$ proliferates rapidly at the cell surface and forms a dense mycelium that sporulates abundantly. Bars $=5 \mu \mathrm{m}$. $\mathbf{C}$ and $\mathbf{D}$, In citrus fruits treated with Verticillium lecanii, close contact is established between $V$. lecanii $(\mathrm{V})$ and P. digitatum $(\mathrm{P})$. Signs of collapse, evidenced by the shrinked appearance of the pathogen cell surface (D, white arrow), are seen. Bars $=5 \mu \mathrm{m}$. E, In chitosan-treated citrus fruits, cells of $P$. digitatum $(\mathrm{P})$ are seriously collapsed. Bar $=5 \mu \mathrm{m}$. Sp, spore. 

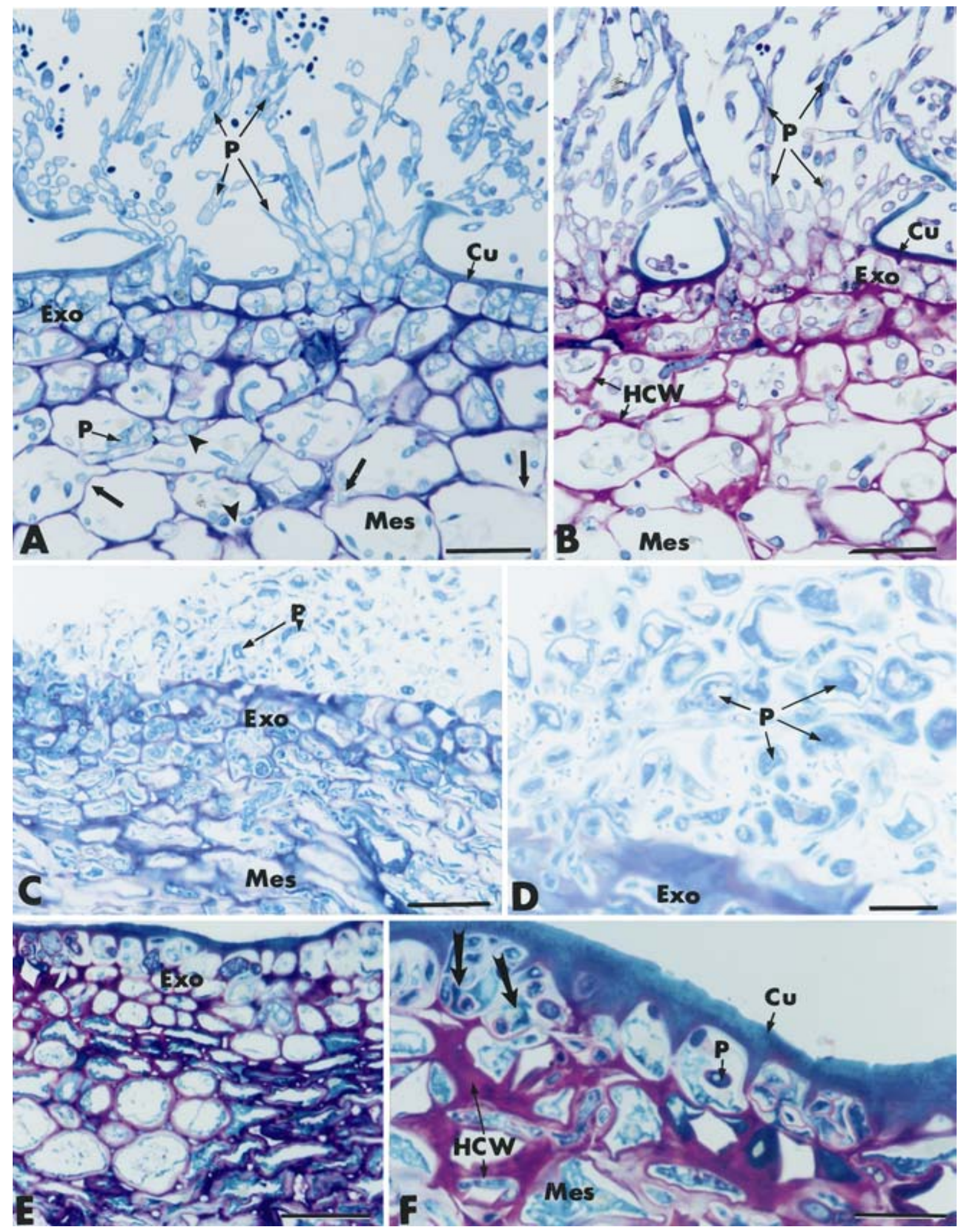

Fig. 3. Light micrographs of samples from wounded citrus fruits inoculated with Penicillium digitatum. A and B, Absence of treatment and inoculation with P. digitatum (control). Hyphae of P. digitatum (P) proliferate throughout the spongy parenchymatous mesocarp (Mes) cells and reach the exocarp (Exo). Host cell wall alterations are visible in places (A, arrows). Fungal cells can be seen in some intercellular spaces (A, arrowheads). Upon incubation of sections with methylene blue-basic fushin, the host cell walls (HCW) stain pink-red. B, Burst of the host cuticle (Cu) leads to the release of $P$. digitatum hyphae (A and B). Bars $=20 \mu \mathrm{m}$. C to F, Treatment with Verticillium lecanii and inoculation with P. digitatum. In the colonized exocarp tissue, hyphae of $P$. digitatum (P) suffer from serious damages, mainly characterized by strong morphological alterations associated with marked cytoplasm disorganization (C and D). Incubation of sections with methylene blue-basic fushin (E and F) shows that the host cell walls (HCW) in the mesocarp (Mes) are thicker than normal and that they stain darker. A material that stains blue-green is seen in some exocarp cells (Exo) (F, arrows). $\mathbf{C}$ and $\mathbf{E}$, Bars $=20 \mu \mathrm{m}$. D and F, Bars $=10 \mu \mathrm{m}$. 
Observations of transversally sectioned samples from wounded citrus fruits that were inoculated with $P$. digitatum (control) showed a pattern of massive fungal colonization (Fig. 3A). Invading hyphae proliferated throughout the spongy parenchymatous mesocarp cells causing rapid tissue maceration (data not shown). Pathogen ingress toward the exocarp coincided with host cell disorganization such as cytoplasm breakdown and host cell wall alterations as illustrated by the decrease in toluidine blue staining intensity of the wall structures in places (Fig. 3A, arrows). Fungal growth occurred mainly intracellularly but could also be seen in some intercellular spaces (arrowheads). Upon incubation of sections with methylene blue-basic fushin, the host cell walls stained pink-red, thus indicating their cellulosic composition (Fig. 3B). Such a massive colonization frequently resulted in a strong mechanical pressure against the host exocarp cells, ultimately leading to an apparent burst of the host cuticle and to the release of the actively multiplying $P$. digitatum hyphae (Fig. 3A and B). By 5 days after inoculation, the host cuticle was perforated in many places and host wall displacement in the direction of pathogen release was easily discernible (Fig. 3B, arrows). Spores, which stained densely with toluidine blue, were frequently seen in the vicinity of released hyphae (Fig. 3A). In all cases, the observed pattern of host cell colonization coincided with the occurrence of macroscopically visible symptoms over citrus fruits.

Examination of samples from $V$. lecanii-treated citrus fruits that were challenged with $P$. digitatum revealed that tissue colonization occurred but to a lesser extent than in control fruits (Fig. 3C to F). A close examination of the colonized, exocarp tissue showed that invading hyphae suffered from serious damages, mainly characterized by strong morphological alterations associated with marked cytoplasm disorganization (Fig. 3C and D). Although rupture of the host cuticle could be seen, the released hyphae were markedly damaged as exemplified by their abnormal shape and the aggregation of the cytoplasmic content (Fig. 3D). Incubation of sections with methylene blue-basic fushin showed that the host cell walls in the parenchymatous spongy mesocarp were much thicker than normal (Fig. 3F) and that they stained darker than in samples from control fruits (Fig. 3E). In most examined samples, the exocarp cells were found to contain a material that stained blue-green (Fig. 3F, arrows). Sporulation was never observed when release of damaged hyphae occurred (Fig. 3C and D).

In samples from chitosan-treated fruits that were challenged with $P$. digitatum, invading hyphae were either highly vacuolated (Fig. 4A, arrows) or completely distorted and aggregated (Fig. 4A and $\mathrm{B}$, double arrows) and, in some cases, reduced to empty hyphal shells (Fig. 4A, arrowhead). Host cell necrotization was frequently observed at sites of attempted pathogen penetration (Fig. 4B).

Cytological and cytochemical investigations of the infection process by $\boldsymbol{P}$. digitatum in wounded citrus fruits. TEM observations of ultrathin sections from untreated citrus fruits inoculated with $P$. digitatum confirmed that fungal invasion was massive and associated with the release of numerous hyphae through perforation of the host cuticle (Fig. 5A). Hyphal cells exhibited a typical ultrastructure with a dense polyribosome-rich cytoplasm in which typical organelles could be seen. Labeling with the WGA-gold complex, for the localization of chitin, resulted in a regular deposition of gold particles over the fungal cell walls while the host cell walls and cuticle were unlabeled (Fig. 5B). Interestingly, a massive accumulation of gold particles was seen in the areas surrounding the released hyphae, suggesting that hyphal cells were embedded in a chitin-enriched matrix (Fig. 5B and $\mathrm{C}$, arrows). Pathogen colonization of the exocarp cells coincided with host cell wall alterations as illustrated by the occurrence of polymorphic areas of digestion (Fig. 5D, double arrows). Such wall alterations disclosed the fibrillar network known to constitute the rigid framework of the plant cell walls (Fig. 6A). Incubation with the gold-complexed exoglucanase for the localization of cellulose subunits resulted in an irregular deposition of gold particles over the structurally altered host walls (Fig. 6A and B). A close examination of the labeling pattern in some areas revealed that gold particles were scattered over the outermost wall
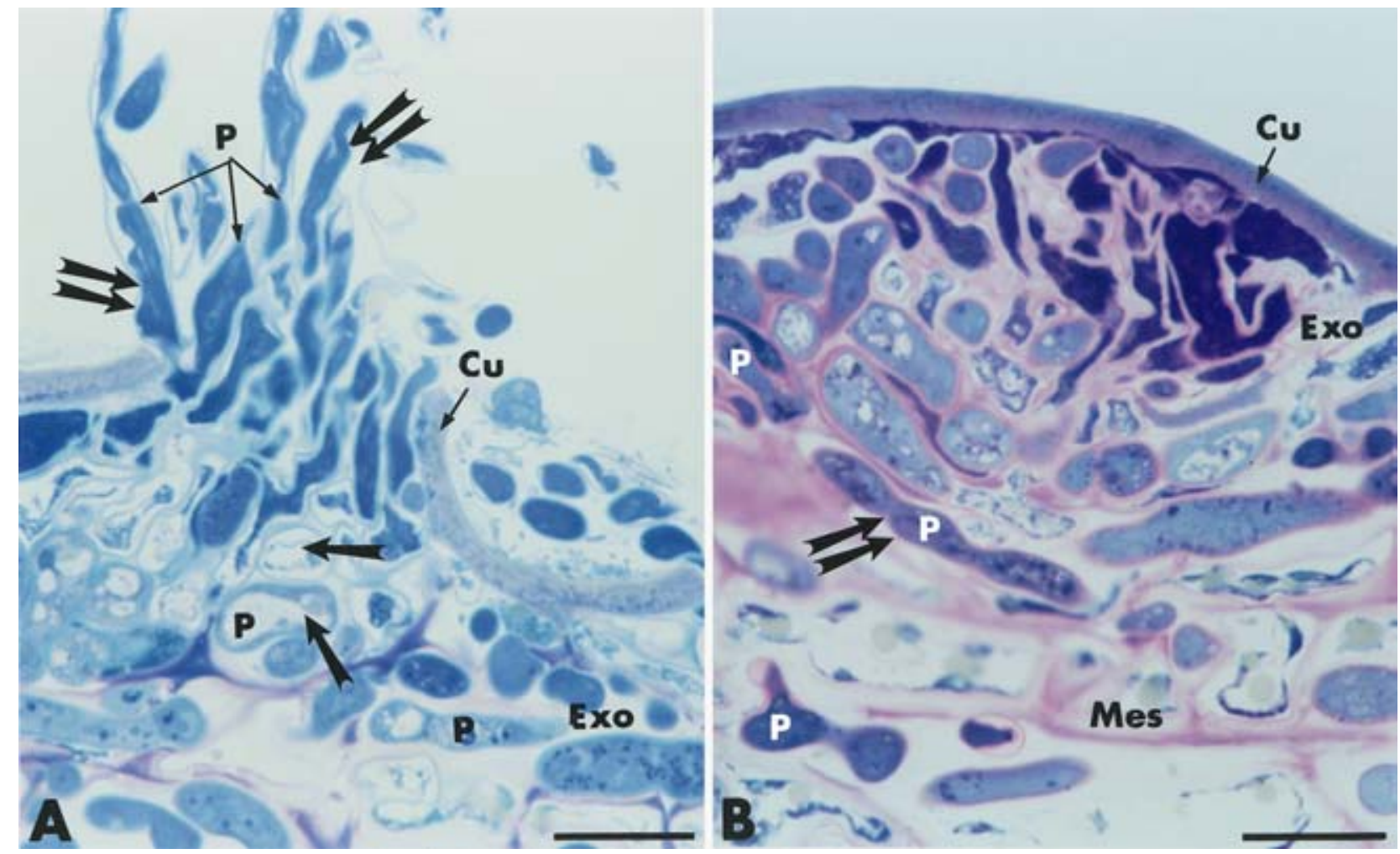

Fig. 4. Light micrographs of samples from chitosan-treated citrus fruits inoculated with Penicillium digitatum. A and B, Host cell necrotization is observed at sites of attempted pathogen penetration $(\mathbf{B})$. Invading hyphae of $P$. digitatum $(\mathrm{P})$ are markedly damaged. Bars $=10 \mu \mathrm{m}$. 
layer of invaded areas while they were nearly absent over the wall portions adjacent to the colonized areas (Fig. 6A and B). Interestingly, wall alterations were visible not only in the areas of potential fungal penetration but also at some distance from these sites as shown by the loss of labeling at a distance from the areas of digestion (Fig. 6C and D). As previously reported (11), cellulose, together with chitin, were found to occur in Penicillium cell walls (Fig. 6A and C). Surprisingly, the cellulose content of the fungal
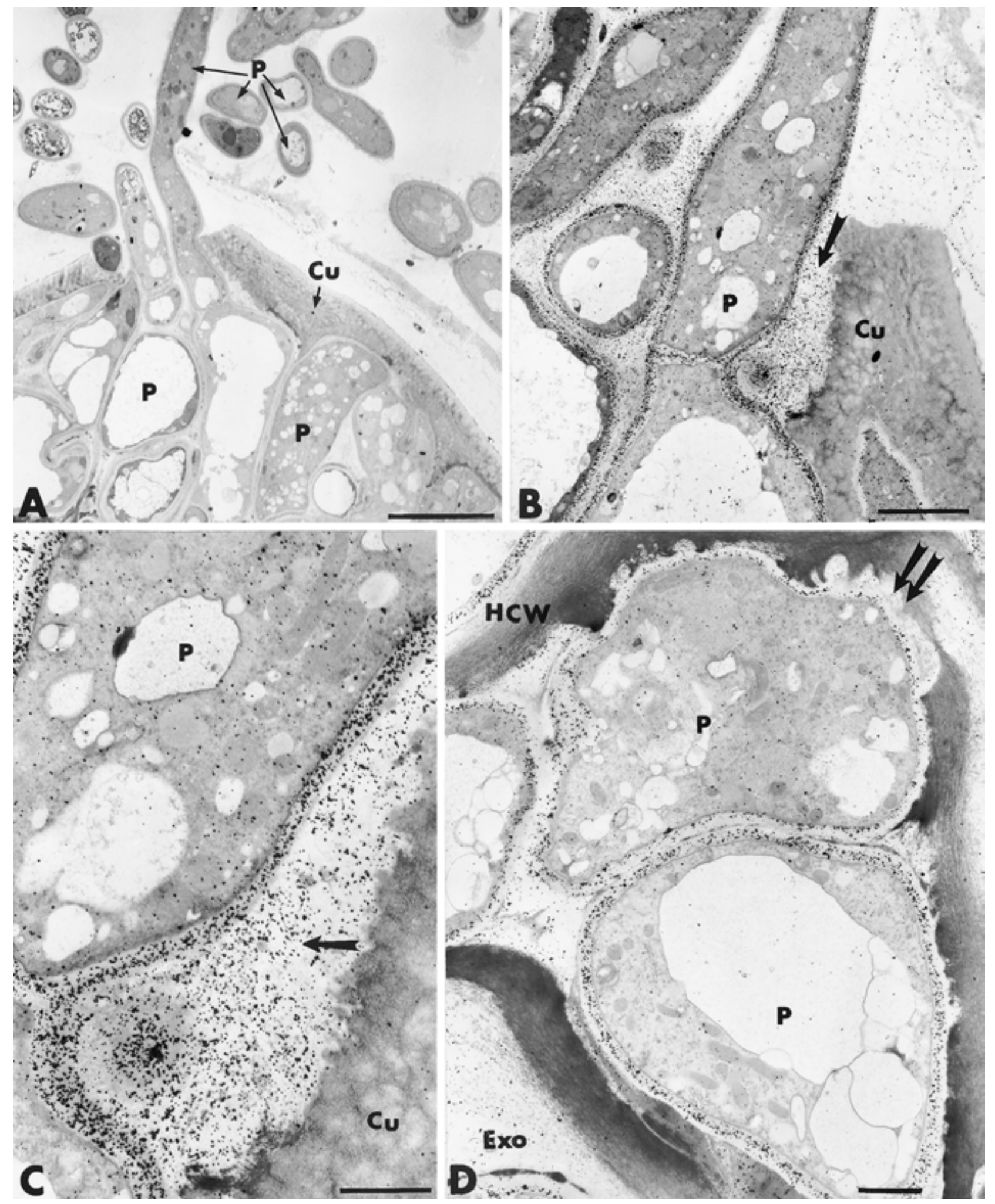

Fig. 5. Transmission electron micrographs of cross sections from wounded citrus fruits inoculated with Penicillium digitatum (control). A to D, Tissue invasion by $P$. digitatum $(\mathrm{P})$ is massive and associated with the release of numerous hyphae through perforation of the host cuticle $(\mathrm{Cu})$. Labeling with the wheat germ agglutinin-gold complex, for the localization of chitin, results in a regular deposition of gold particles over the fungal cell walls (B). A massive accumulation of gold particles is seen in the areas surrounding the released hyphae (B and C, arrows). Pathogen colonization of the exocarp cells (Exo) coincides with host cell wall $(\mathrm{HCW}$ ) alterations as illustrated by the occurrence of polymorphic areas of digestion (D, double arrows). A, Bar $=10 \mu \mathrm{m} ; \mathbf{B}, \mathrm{Bar}=2.5 \mu \mathrm{m} ; \mathbf{C}$ and $\mathbf{D}$, Bars $=1 \mu \mathrm{m}$. 
cell wall was not altered at a time when the cellulosic framework of the plant cell wall was seriously damaged (Fig. 6D).

Cytological and cytochemical investigations of the effect of $V$. lecanii on growth of $P$. digitatum in wounded citrus fruits. Observation of numerous sections from a minimum of five differ- ent samples provided evidence that most hyphae of the pathogen (about 90\%) that penetrated the spongy parenchymatous mesocarp tissue in the immediate vicinity of the infection sites were usually distorted (Fig. 7) and exhibited considerable changes including plasmalemma disruption and marked cytoplasm disor-
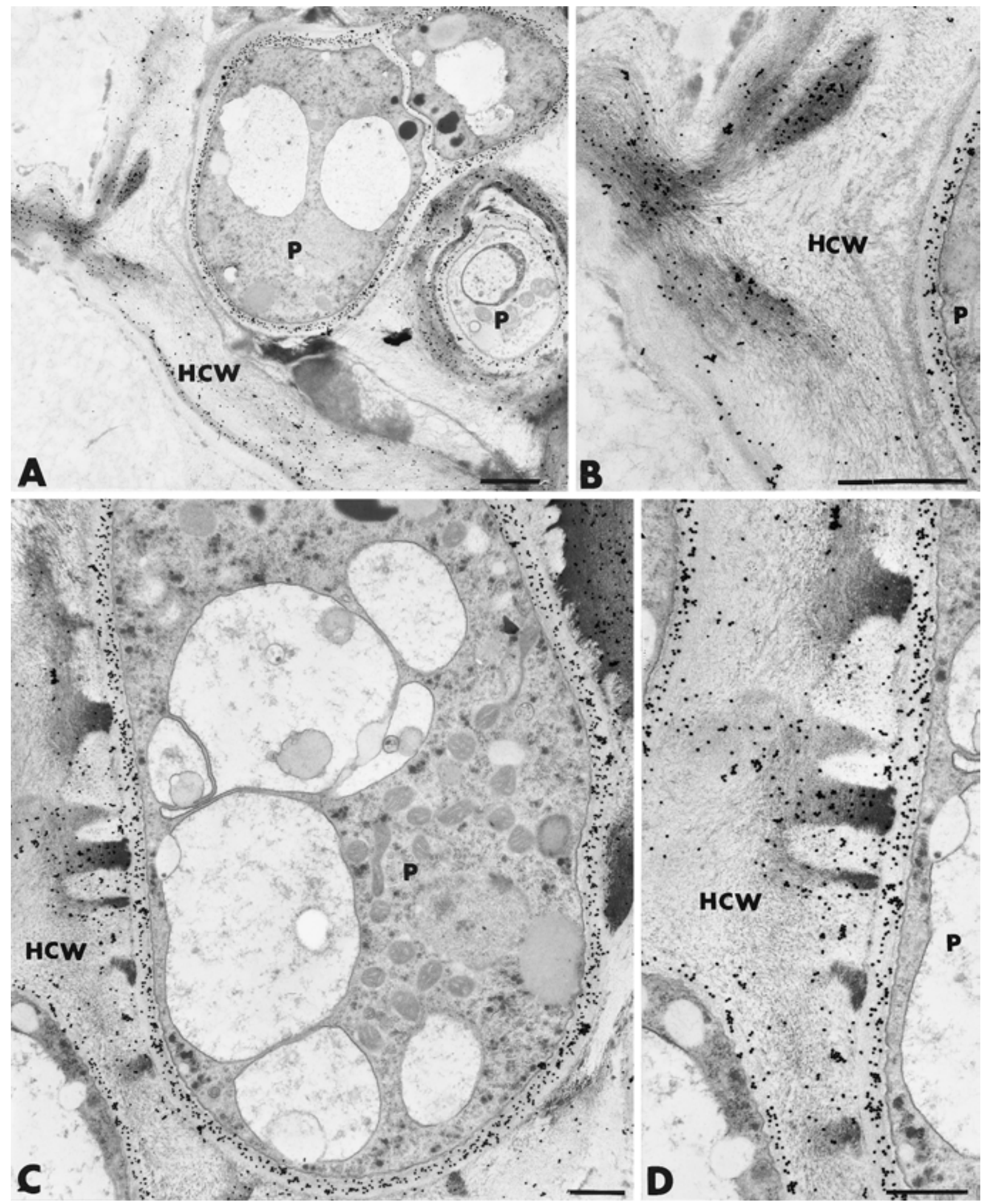

Fig. 6. Transmission electron micrographs of cross sections from wounded citrus fruits inoculated with Penicillium digitatum (control). A and B, Incubation with the gold-complexed exoglucanase for the localization of cellulose subunits results in an irregular deposition of gold particles over the structurally altered host walls $(\mathrm{HCW})$. Some wall areas are nearly free of labeling. Cell walls of P. digitatum $(\mathrm{P})$ are labeled. Bars $=1 \mu \mathrm{m}$. C and $\mathbf{D}$, Host cell wall (HCW) alterations are visible at a distance from the sites of fungal penetration. Bars $=0.5 \mu \mathrm{m}$. 
ganization (Fig. 7B). Incubation of ultrathin sections with the WGA/ovomucoid-gold complex resulted in an irregular labeling of Penicillium cell walls (Fig. 7B) even when hyphae were nearly reduced to empty shells. A close examination of the labeling pat- tern revealed that, in most invading hyphae, some wall areas were unlabeled (Fig. 7D, arrow). Hyphae of V. lecanii were frequently seen in the vicinity of the altered Penicillium cells (Fig. 7A and C). However, features of mycoparasitism similar to those seen at
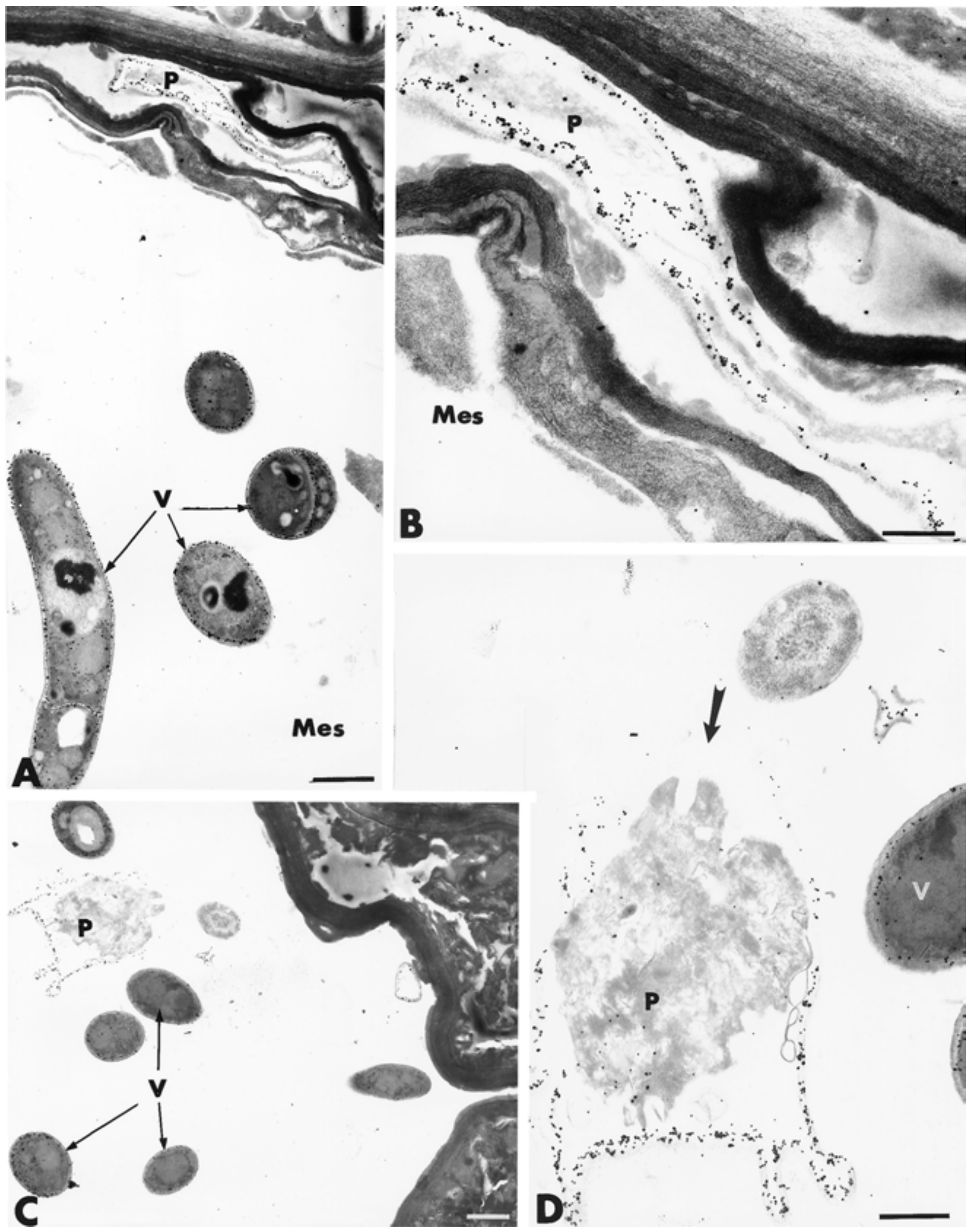

Fig. 7. Transmission electron micrographs of cross sections from Verticillium lecanii-treated citrus fruits inoculated with Penicillium digitatum. A and B, In the spongy parenchymatous mesocarp tissue (Mes), hyphae of P. digitatum $(\mathrm{P})$ are markedly altered. Upon incubation with the wheat germ agglutinin/ovomucoidgold complex, Penicillium cell walls are irregularly labeled $(\mathbf{B})$. Hyphae of $V$. lecanii $(\mathrm{V})$ are frequently seen in the vicinity of the altered Penicillium cells. A and $\mathbf{B}$, Bars $=0.5 \mu \mathrm{m}$. C and D, Large unlabeled wall areas are seen in some highly altered Penicillium hyphae (P) neighboring cells of V. lecanii (V) (D, arrow). C, Bar $=1 \mu \mathrm{m}$; and $\mathbf{D}$, Bar $=0.5 \mu \mathrm{m}$. 


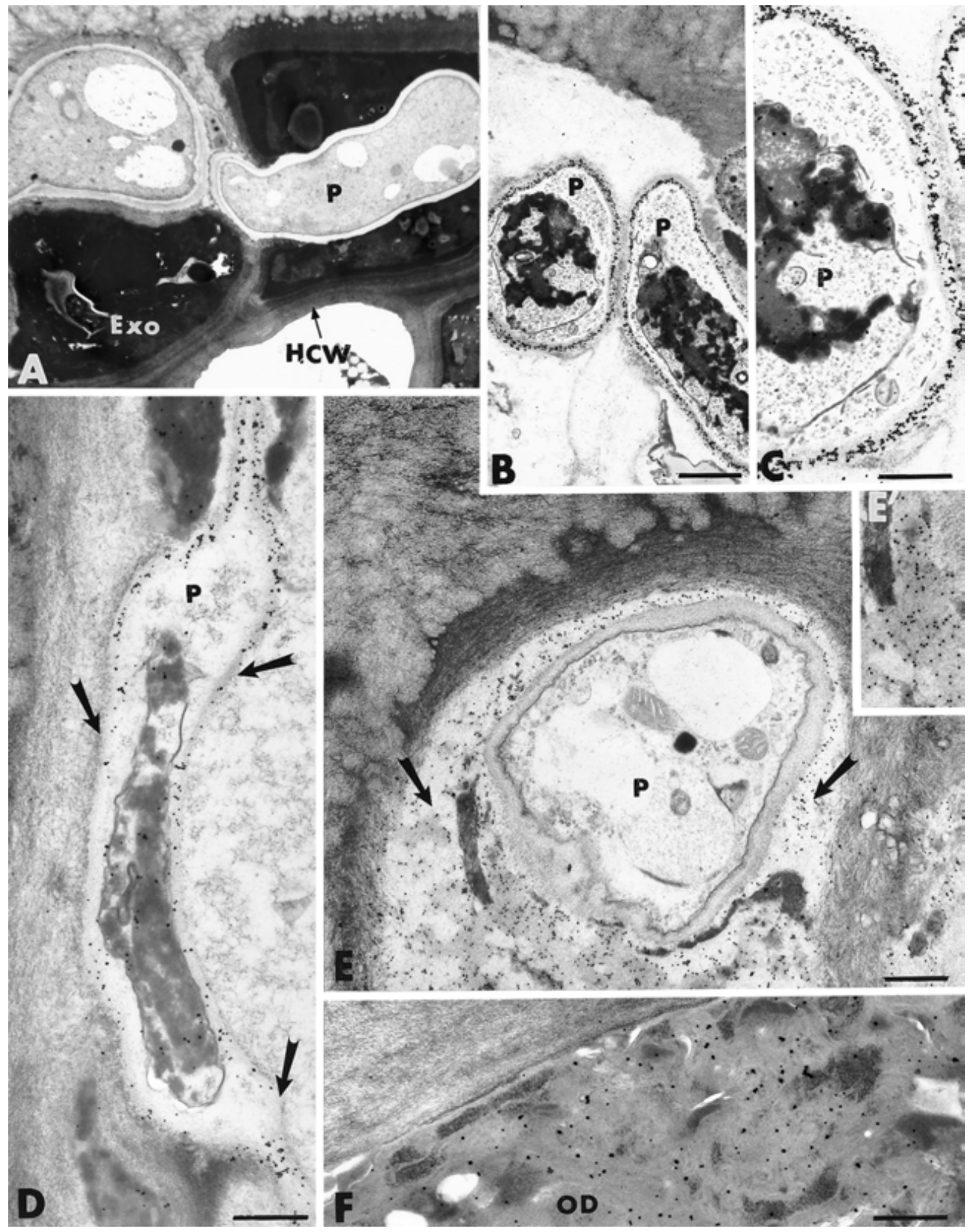

Fig. 8. Transmission electron micrographs of cross sections from Verticillium lecanii-treated citrus fruits inoculated with Penicillium digitatum. A, Cells of the colonized exocarp (Exo) are frequently necrotized. The host cell walls (HCW) appear electron-dense. Bar $=2 \mu \mathrm{m}$. B and $\mathbf{C}$, In other exocarp cells (Exo) where the necrotization process did not apparently occur, cells of the pathogen are highly damaged as judged by the strong alteration of the cytoplasm, which is reduced to aggregated remnants. Labeling with the wheat germ agglutinin (WGA)/ovomucoid-gold complex results in a quite regular labeling of the fungal cell wall. B, Bar $=1 \mu \mathrm{m} ; \mathbf{C}, \mathrm{Bar}=0.5 \mu \mathrm{m}$. D, Labeling with the WGA/ovomucoid-gold complex is markedly reduced or even absent over large wall portions of a highly damaged hypha of $P$. digitatum (P) (arrows). Bar $=0.5 \mu \mathrm{m}$. E and $\mathbf{E}^{\prime}$, Labeling of callose with the gold-complexed $\beta-1,3$-glucanase. Gold particles accumulate in the space previously occupied by the host cytoplasm in a colonized cell of the exocarp (arrows). The pathogen cell (P) appears trapped in the callose-enriched matrix. $\mathbf{E}$, Bar $=1 \mu \mathrm{m} ; \mathbf{E}^{\prime}$, Bar $=0.5 \mu \mathrm{m}$. F, Labeling with the gold-complexed laccase for the localization of lignin-like compounds. A specific deposition of gold particles occurs over the osmiophilic deposits (OD) accumulating in necrotized exocarp cells. 
the cell surface were not detected. In these areas surrounding the site of fungal interaction, mesocarp cells exhibited signs of necrotization mainly characterized by cytoplasmic aggregation and host cell wall distortion (Fig. 7C).

In the exocarp, most host cells (about 70\%) invaded by hyphae of $P$. digitatum were severely altered judged by their necrotizing aspect. In such host cells, the cytoplasm was completely aggregated and preexisting organelles such as nuclei and mitochondria were no longer discernible. Interestingly, the cell walls were not apparently damaged. Instead, they appeared, in some areas, to be impregnated by osmiophilic substances judged by the marked increase of their electron density (Fig. 8A). In other exocarp cells, the necrotization process did not apparently occur (Fig. 8B). However, cells of the pathogen growing in these reactive host cells displayed marked changes in their ultrastructure such as retraction of the plasmalemma from the cell wall and alteration of the cytoplasm which was, most often, reduced to aggregated remnants (Fig. 8B and C). When the WGA/ovomucoid-gold complex was applied to sections of $V$. lecanii-treated citrus fruits, variations in the pattern of pathogen wall labeling was noticed (Fig. 8B to E). Gold labeling could, indeed, be evenly distributed over the walls of invading hyphae even when those were substantially altered (Fig. 8B and C), whereas it was markedly reduced or even absent over large wall portions of highly damaged hyphae (Fig. $8 \mathrm{D}$, arrows). Whereas hyphae of $V$. lecanii were frequently seen in the parenchymatous mesocarp, they were seldom detected in the exocarp tissue.

Interestingly, labeling with the $\beta$-1,3-glucanase-gold complex for the localization of callose revealed that gold particles accumulated in the space previously occupied by the host cytoplasm (Fig. $8 \mathrm{E})$. A close examination showed that labeling was most predominantly associated with amorphous deposits surrounding cytoplasmic remnants (Fig. 8E and E', arrows). Pathogen cells were apparently trapped in this matrix.

Incubation of sections with the gold-complexed laccase for the localization of lignin-like compounds resulted in a specific deposition of gold particles over the osmiophilic deposits accumulating in necrotized exocarp cells (Fig. 8F).

Cytological and cytochemical investigations of the effect of chitosan on growth of $P$. digitatum in wounded citrus fruits. In wounded citrus fruits treated with chitosan and inoculated with $P$. digitatum, fungal growth was markedly reduced (Fig. 9A). Such fungal growth restriction coincided with pronounced disorganization of the exocarp cells (Fig. 9A and B). Host cells at penetration sites exhibited signs of severe disorganization (Fig. 9A). In such morphologically altered host cells, cytoplasm aggregation and cell wall distortion were among the most typical features of reaction (Fig. 9A). Interestingly, the contorted epidermal cell walls were not apparently damaged judged by the quite regular labeling obtained with the gold-complexed exoglucanase (Fig. 9B). Cells of the pathogen growing in these necrotic epidermal cells displayed marked changes in their morphology and ultrastructure (data not shown).

\section{DISCUSSION}

Results of the present study provide the first evidence that $V$. lecanii, a powerful antagonistic fungus (11), has the ability, under experimental conditions, to reduce green mold incidence caused by $P$. digitatum. Provided that the results obtained in this study can be confirmed under commercial conditions, then the ability of $V$. lecanii to both antagonize $P$. digitatum and induce host resistance would be of powerful value for the biological control of citrus green mold.

Reduction of disease incidence in citrus fruits following treatment with either chitosan or V. lecanii coincided with marked host metabolic changes. The main facets of this altered metabolism concerned the induction of a response resembling hypersensitivity in the exocarp tissues and the abnormal accumulation of osmiophilic substances in the tissue layers underlying the sites of fungal penetration. Even though our cytological results support the idea that the beneficial effect of chitosan and $V$. lecanii is mainly associated with an increased resistance to infection, the possibility that both treatments may have exerted a direct inhibitory effect on hyphal growth at the inoculated wound sites cannot be ruled out in view of the occurrence of altered Penicillium hyphae at the cell surface. In untreated citrus fruits, injury into the parenchymatous mesocarp tissue preceded massive colonization of the mesocarp cells by $P$. digitatum and rapid hyphal penetration into the exocarp. In presence of $V$. lecanii, invasion of the
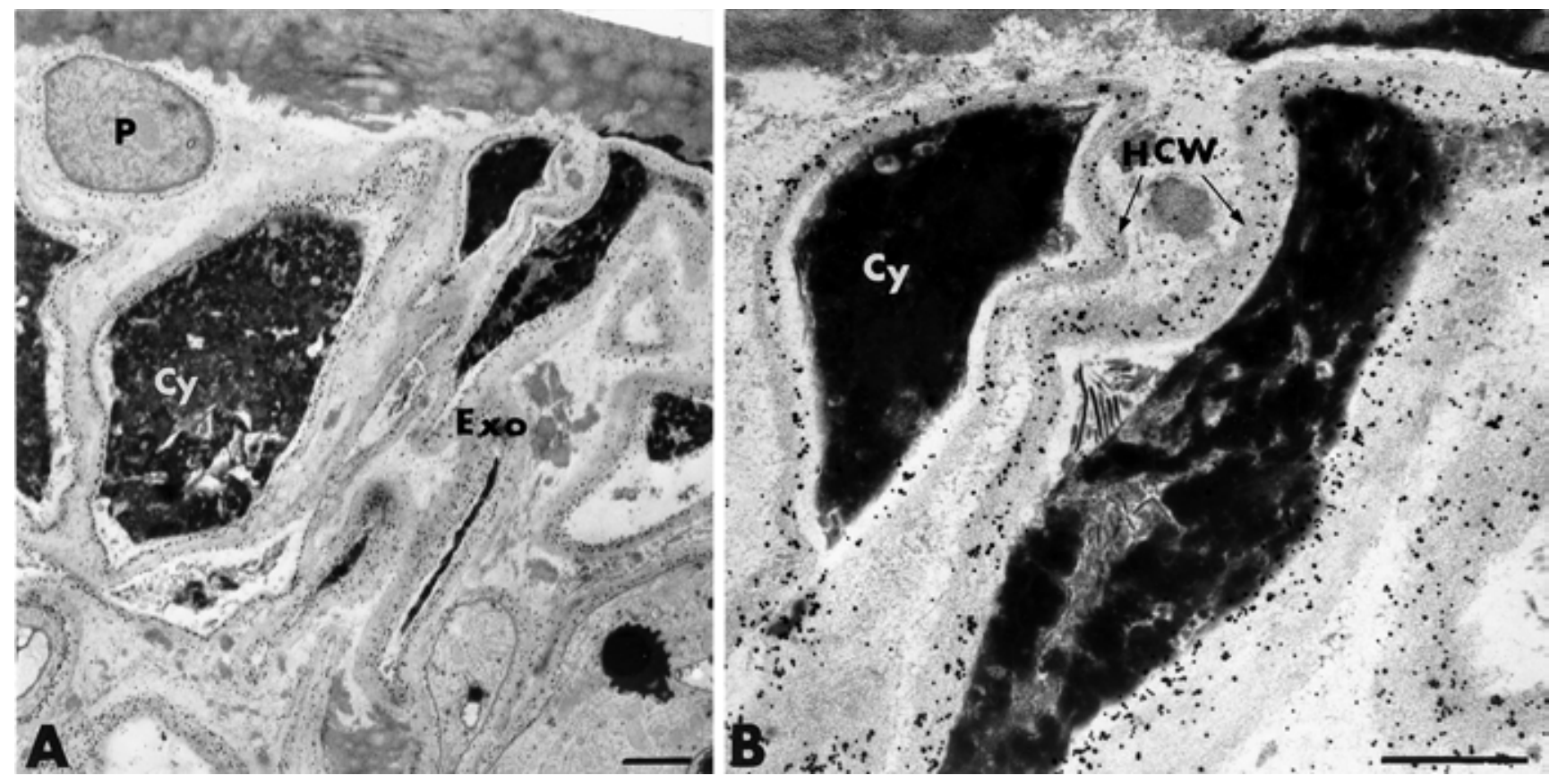

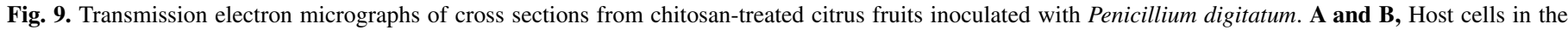

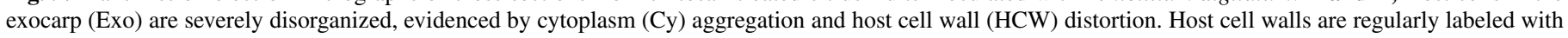
the gold-complexed exoglucanase (B). 
mesocarp tissue was apparently impaired by the presence of the antagonist. Observation of numerous cells of the invaded mesocarp tissue showed that the presence of $V$. lecanii in the vicinity of $P$. digitatum hyphae was always associated with a series of fungal cell disturbances (i.e., plasmalemma retraction, cytoplasm aggregation, and cell wall alteration) similar to those previously noticed in the in vitro investigation of the interaction between $V$. lecanii and $P$. digitatum (11). These results support the current concept that $V$. lecanii has the potential to affect the growth of several plant pathogens by producing a wide range of metabolites and enzymes $(17,32,42)$. One may thus speculate that antibiosis as well as enzymatic hydrolysis may be associated with a significant reduction of the pathogen population in the mesocarp tissue, that, in turn, reduce or delay extensive spread of the pathogen. Whether the observed fungal damage, especially in the parenchymatous mesocarp tissue, results from the synergistic action of plant defense molecules and toxins produced by the antagonistic fungus remains to be determined. In that context, the observation that hyphae of the pathogen reached the exocarp tissue in spite of direct inhibitory effect on hyphal growth in the mesocarp tissue not only indicates that this first defensive line is not completely efficient in halting pathogen ingress toward the exocarp but also that another strategy, elaborated by the host, accounts for the observed reduction of disease incidence. Similar observations were made with chitosan, although its antifungal activity, as shown by the rapid collapse and loss of turgor of $P$. digitatum hyphae at the fruit surface, was apparently stronger than that of $V$. lecanii. In spite of these slight differences in terms of antimicrobial activity, the most interesting effect of both treatments in citrus fruits was the development of marked changes in the host physiology, suggesting the stimulation of defense genes leading to the synthesis and accumulation of newly formed defense products.

In pathogen-inoculated fruits, rapid necrotrophic colonization of inner and outer tissues was accompanied by major host cell disorganization without abnormal accumulation of structural defense-related features. The labeling pattern of cellulose provided evidence that the fungus was able to produce cell wall-degrading enzymes that diffused at a distance from the areas of penetration, leading eventually to disruption of primary walls and tissue maceration. Our cytological observations revealed that the fungus colonized rapidly and massively the spongy parenchymatous mesocarp cells before penetrating the more compact cells of the exocarp. Fungal release through perforation of the cuticle occurred always after extensive invasion and degradation of the outermost tissue layers. Considering that ingress from the injured mesocarp tissue toward the exocarp is an essential prerequisite for successful pathogenesis (7), host cell wall degradation is obviously one of the most deleterious events occurring during the infection process of citrus fruits. Understandably, success of the host in warding off pathogen spread relies primarily on its capability of elaborating rapidly structural and biochemical processes for protecting the cell walls against both penetration and enzymatic degradation (15). Results from the present study confirm that modifications of the host cell walls as well as deposition of newly formed material occur in treated citrus fruits in response to pathogen attack. Dramatic cellular changes, characterized by rapid necrotization of the host exocarp cells, a phenomenon usually referred to as hypersensitive reaction (HR), were indeed typical features of reaction observed in the infected exocarp tissue following treatment with $V$. lecanii and chitosan. Considering the importance of these cellular changes in restricting fungal spread and shielding the neighboring tissues from phytotoxic substances such as hydrolytic enzymes and toxins, it was essential to determine whether they were more than a physical barrier designed to only prevent pathogen penetration. Attempts of pathogen hyphae to grow in these reactive tissues resulted in severe structural alterations, suggesting that the environment was fungicidal, a concept that was further confirmed by the detection of phenolic-like sub- stances in the reactive host cells (Fig. 8). In addition, the observation that chitin molecules still occurred over the walls of highly disorganized fungal cells was taken as an indication that chitinases were probably not the first antimicrobial compounds involved in the process of fungal growth inhibition in planta.

Section labeling with the gold-complexed laccase, a coppercontaining polyphenol oxidase, mainly produced by wood rotting fungi (39) and known to play a key role in both lignin breakdown (18) and oxidation of endogenous plant phenols (37), resulted in the specific deposition of gold particles over the electron-dense material occluding reactive host cells (Fig. 7F). The labeling pattern obtained with the gold-complexed laccase indicated that treatments with $V$. lecanii and chitosan likely stimulated the de novo synthesis of phenolic compounds (i.e., lignin) and/or the polymerization of preexisting free, soluble phenols. In line with these cytochemical observations, the histological test based on the use of methylene blue-basic fushin, a staining method allowing to differentiate cellulose from lignin, provided a clear image of the pattern of lignin deposition in the infected areas of treated citrus fruits. The finding that the exocarp cells contained a material that stained blue-green suggested the accumulation of phenolic-like compounds in such reactive cells. As previously suggested by Brown and Barmore (19), enrichment of the exocarp tissue with phenolics is likely to contribute to the elaboration of permeability barriers preventing pathogen spread and enzymatic degradation. Several studies have convincingly shown that phenolic substances could confer strong cell rigidity through peroxidase-mediated cross-linking with preexisting carbohydrates such as hemicellulose, pectin, and callose (30). The finding that callose accumulated in citrus exocarp tissues upon treatment with $V$. lecanii or chitosan and pathogen challenge, suggests that the deposited material is made of a polysaccharidic matrix mainly composed of callose on which phenolic compounds (likely lignin) are sequentially deposited, probably to build a more impervious composite.

The relative importance of phenolic compounds in the protection of citrus tissues against fungal attack is a well-documented process $(24,41)$. Several lines of evidence have shown that stimulation of the secondary metabolism is a typical feature of reaction to various postharvest treatments $(22,35,40)$. Results of the present cytochemical study support the concept that the onset of induced resistance in citrus fruit is associated with the production and accumulation of secondary metabolites which may play a key role by directly inhibiting pathogen growth due to their antimicrobial potential and indirectly protecting the tissues underlying or neighboring the invaded areas by acting as a mechanical barrier capable of restricting fungal spread.

Our results demonstrate that $V$. lecanii as well as chitosan are equally capable of inducing a striking response in $P$. digitatuminfected citrus fruits when exogenously applied prior to fungal infection. Although it is clear that reduction of disease incidence results from the synergistic action of several mechanisms, the induction of a specific host response appears to play a key role in the control of citrus green mold by $V$. lecanii. Today, an improved protection program implies the availability of highly efficient biofungicides. Due to its biological properties, the mycoparasite, $V$. lecanii, offers good prospects for integrated citrus disease management although unequivocal answers to key questions including human safety, efficiency under commercial conditions, and suitability in an integrated fruit protection system need to be answered before it can be considered as a powerful postharvest protectant.

\section{ACKNOWLEDGMENTS}

This study was supported by grants from the Natural Sciences and Engineering Research Council of Canada (NSERC) and the Fonds Québécois de la Recherche sur la Nature et les Technologies (FQRNT). I thank A. Goulet and C. Garand for excellent technical assistance, M. Nicole (IRD, Montpellier, France) for providing the purified laccase, 
and J. Brodeur (Laval University, Quebec, Canada) for providing V. lecanii obtained from W. R. Jarvis, Harrow Research Station Agriculture and Agrifood Canada, Ontario.

\section{LITERATURE CITED}

1. Aparicio, S. R., and Marsden, P. 1968. A rapid methylene blue-basic fushin stain for semi-thin sections of peripheral nerve and other tissues. J. Microsc. 89:139-141.

2. Arras, G. 1996. Mode of action of an isolate of Candida famata in biological control of Penicillium digitatum in orange fruits. Postharvest Biol. Technol. 8:191-198.

3. Arras, G., De Cicco, V., and Lima, G. 1998. Biocontrol by yeasts of blue mould of citrus fruits and the mode of action of an isolate of Pichia guilliermondii. J. Hortic. Sci. Biotechnol. 73:413-418.

4. Arras, G., and D'hallewin, G. 1994. In vitro and in vivo control of Penicillium digitatum and Botrytis cinerea in citrus fruit by Bacillus subtilis strains. Agric. Med. 124:56-61.

5. Askary, H., Benhamou, N., and Brodeur, J. 1997. Ultrastructural and cytochemical investigations of the antagonistic effect of Verticillium lecanii on cucumber powdery mildew. Phytopathology 87:359-368.

6. Askary, H., Carrière, Y., Bélanger, R. R., and Brodeur, J. 1998. Pathogenicity of the fungus Verticillium lecanii to aphids and powdery mildew. Biocontrol Sci. Technol. 8:23-32.

7. Barmore, C. R., and Brown, G. E. 1981. Polygalacturonase from citrus fruit infected with Penicillium italicum. Phytopathology 71:328-331.

8. Benhamou, N. 1989. Preparation and application of lectin-gold complexes. Pages 95-143 in: Colloidal Gold, Principles, Methods, and Applications, Vol. 1. M. A. Hayat, ed. Academic Press, New York.

9. Benhamou, N. 1992. Ultrastructural detection of $\beta$-1,3-glucans in tobacco root tissues infected by Phytophthora parasitica var. nicotianae using a gold-complexed tobacco $\beta$-1,3-glucanase. Physiol. Mol. Plant Pathol. 41:351-370.

10. Benhamou, N. 1996. Elicitor-induced plant defense pathways. Trends Plant Sci. 1:233-240.

11. Benhamou, N., and Brodeur, J. 2000. Evidence for antibiosis and induced host defense reactions in the interaction between Verticillium lecanii and Penicillium digitatum, the causal agent of green mold. Phytopathology 90:932-943.

12. Benhamou, N., and Brodeur, J. 2001. Pre-inoculation of Ri T-DNA transformed cucumber roots with the mycoparasite, Verticillium lecanii, induces host defense reactions against Pythium ultimum infection. Physiol. Mol. Plant Pathol. 58:133-146.

13. Benhamou, N., Chamberland, H., Ouellette, G. B., and Pauzé, F. J. 1987. Ultrastructural localization of $\beta$-1,4-D-glucans in two pathogenic fungi and in their host tissues by means of an exoglucanase-gold complex. Can. J. Microbiol. 33:405-417.

14. Benhamou, N., and Lafontaine, P. J. 1995. Ultrastructural and cytochemical characterization of elicitor-induced responses in tomato root tissues infected by Fusarium oxysporum f. sp. radicis-lycopersici. Planta 197:89102.

15. Benhamou, N., Lafontaine, P. J., and Nicole, M. 1994. Seed treatment with chitosan induces systemic resistance to Fusarium crown and root rot in tomato plants. Phytopathology 84:1432-1444.

16. Benhamou, N., and Thériault, G. 1992. Treatment with chitosan enhances resistance of tomato plants to the crown and root rot pathogen Fusarium oxysporum f. sp. radicis-lycopersici. Physiol. Mol. Plant Pathol. 41:33-52.

17. Bidochka, M. J., and Burke, S., and Ng, L. 1999. Extracellular hydrolytic enzymes in the fungal genus Verticillium: Adaptations for pathogenesis. Can. J. Microbiol. 45:856-864.

18. Blanchette, R. A. 1991. Delignification by wood-decay fungi. Annu. Rev. Phytopathol. 29:381-398.

19. Brown, G. E., and Barmore, C. R. 1983. Resistance of healed citrus exocarp to penetration by Penicillium digitatum. Phytopathology 73:691-694.

20. Bull, C. T., Stack, J. P., and Smilanick, J. L. 1997. Pseudomonas syringae strains ESC-10 and ESC-11 survive in wounds on citrus and control green and blue molds of citrus. Biol. Control 8:81-88.

21. Ceponis, M. J., Cappellini, R. A., and Lightner, G. W. 1986. Disorders in citrus shipments to the New York market. Plant Dis. 70:1162-1165.

22. Chalutz, E., Droby, S., Wilson, C. L., and Wisniewski, M. E. 1992. UVinduced resistance to postharvest diseases of citrus fruit. J. Photochem. Photobiol. 15:367-374.

23. Droby, S., Hofstein, R., Wilson, C. L., Wisniewski, M., Fridendler, B., Cohen, L., Weiss, B., Daus, A., Timar, D., and Chalutz, E. 1993. Pilot testing of Pichia guilliermondii: A biocontrol agent of postharvest diseases of citrus fruits. Biol. Control 3:47-52.

24. Droby, S., Vinokur, V., Weiss, B., Cohen, L., Dauss, A., Goldschmidt, E. E., and Porat, R. 2002. Induction of resistance to Penicillium digitatum in grapefruit by the yeast biocontrol agent Candida oleophila. Phytopathology 92:393-399.

25. El Ghaouth, A. 1998. Use of elicitors to control postharvest diseases in fruits and vegetables. Pages 90-98 in: Disease Resistance in Fruit. G. I. Johnson, E. Highley, and D. C. Joyce, eds. Aust. Cent. Int. Agri. Res., Australia.

26. El Ghaouth, A., Arul, J., Grenier, J., and Asselin, A. 1992. Antifungal activity of chitosan on two post-harvest pathogens of strawberry fruits. Phytopathology 82:398-402.

27. El Ghaouth, A., Smilanick, J. L., Brown, G. E., Ippolito, A., Wisniewski, M., and Wilson, C. L. 2000. Applications of Candida saitoana and glycochitosan for the control of postharvest diseases of apple and citrus fruit under semi-commercial conditions. Plant Dis. 84:243-248.

28. El Ghaouth, A., Wilson, C. L., and Callahan, A. M. 2003. Induction of chitinase, $\beta-1,3$-glucanase, and phenylalanine ammonia lyase in peach fruit by UV-C treatment. Phytopathology 93:349-355.

29. Frens, G. 1973. Controlled nucleation for regulation of the particle size in monodisperse gold solutions. Nature ( London ) Phys. Sci. 241:20-22.

30. Fry, S. C. 1986. Polymer-bound phenols as natural substrates of peroxidases. Pages 169-182 in: Molecular and Physiological Aspects of Plant Peroxidase. H. Greppin, C. Penel, and Th. Gaspar, eds. Université de Genève, Switzerland.

31. Geiger, J. P., Rio, B., Nandris, D., and Nicole, M. 1986. Laccases of Rigidoporus lignosus and Phellinus noxius; 1 . Purification and some physicochemical properties. Appl. Biochem. Biotechnol. 12:121-133.

32. Gindin, G., Barash, I., Harari, N., and Raccah, B. 1994. Effect of endotoxic compounds isolated from Verticillium lecanii on the sweet potato whitefly, Bemisia tabaci. Phytoparasitica 22:189-196.

33. Huang, Y., Wild, B. L., and Morris, S. C. 1992. Postharvest biological control of Penicillium digitatum decay on citrus fruit by Bacillus pumilus. Ann. Appl. Biol. 120:367-372.

34. Janisiewicz, W. J., and Korsten, L. 2002. Biological control of pastharvest diseases of fruits. Annu. Rev. Phytopathol. 40:411-441.

35. Kim, J. J., Ben-Yehoshua, S., Shapiro, B. M., Henis, Y., and Carmeli, S. 1991. Accumulation of scorapone in heat-treated lemon fruit inoculated with Penicillium digitatum Sacc. Plant Physiol. 97:880-885.

36. Kúc, J. 1987. Plant immunization and its applicability for disease control. Pages 255-274 in: Innovative Approaches to Plant Disease Control. I. Chet, ed. John Wiley \& Sons, New York.

37. Mayer, A. M. 1987. Polyphenol oxidases in plants: Recent progress. Phytochemistry 26:11-20.

38. Raghavendra-Rao, N. N., and Pagvi, M. S. 1977. Two mycoparasites on powdery mildews. Sydowia 30:145-147.

39. Reinhammar, B. 1984. Laccases. Pages 2-35 in: Copper Proteins and Copper Enzymes. Vol. 3. R. Lontie, ed. CRC Press, Boca Raton, FL.

40. Riov, J. 1971. 6,7-Dimethoxycoumarin in the peel of gamma-irradiated grapefruit. Phytochemistry 10:1923.

41. Rodov, V., Ben-Yehoshua, S., Abbaglis, R., and Fang, D. 1994. Accumulation of phytoalexins scorapone and scopoletin in citrus fruits subjected to various post-harvest treatments. Acta Hortic. 381:517-523.

42. Saksirirat, W., and Hoppe, H. H. 1990. Secretion of extracellular enzymes by Verticillium psalliotae Treshow and Verticillium lecanii (Zimm.) Viegas during growth on uredospores of the soybean rust fungus (Phakopsora pachyrhizi Syd.) in liquid cultures. J. Phytopathol. 131:161-173.

43. Schreiter, G., Butt, T. M., Beckett, A., Vestergaard, S., and Moritz, G. 1994. Invasion and development of Verticillium lecanii in the western flower thrips, Frankliniella occidentalis. Mycol. Res. 98:1025-1034.

44. Spencer, D. M., and Atkey, P. T. 1981. Parasitic effects of Verticillium lecanii on two rust fungi. Trans. Br. Mycol. Soc. 77:535-542.

45. Tuzun, S., and Kloepper, J. W. 1995. Practical application and implementation of induced resistance. Pages 152-168 in: Induced Resistance to Disease in Plants. R. Hammerschmidt and J. Kùc, eds. Kluwer Academic Press, Dordrecht, The Netherlands.

46. Wilson, C. L., El Ghaouth, A., Chalutz, E., Droby, S., Stevens, C., Lu, J. Y., Khan, V., and Arul, J. 1994. Potential of induced resistance to control postharvest diseases of fruits and vegetables. Plant Dis. 78:837843.

47. Yedidia, I., Benhamou, N., Kapulnik, Y., and Chet, I. 2000. Activation of plant defense responses following the colonization and penetration of cucumber roots by Trichoderma harzianum. Plant Physiol. Biochem. 38:863-873. 